\title{
KEBERHASILAN IMPLEMENTASI SISTEM INFORMASI AKUNTANSI DALAM PERSPEKTIF KOMITMEN ORGANISASIONAL DAN PENGETAHUAN MANAJER
}

\author{
Mochammad Ridwan \\ mridwan@unpas.ac.id \\ Budi Septiawan \\ Sasa S. Suratman \\ Universitas Pasundan \\ Jln. Tamansari No. 6-8 Bandung
}

diterima: 20/2/2019; direvisi: 25/5/2019; disetujui: 30/10/2019

\begin{abstract}
This study aims to determine the influence of organizational commitment and knowledge of accounting managers on the successful implementation of accounting information systems either simultaneously or partially. It was conducted at SOE in West Java. The research method used were descriptive and verification method. The number of samples were 33 companies, with a simple random sampling technique. The type of data is primary data obtained through a questionnaire distributed to the accounting department manager. The analysis used is multiple linier regression analysis. The results indicated that the level of organizational commitment and the successful implementation of accounting information systems are in the high category, the knowledge of accounting managers is in the very high category. Either simultaneously or partially organizational commitment and knowledge of accounting managers have a positive and significant effect on the successful implementation of accounting information systems at SOE in West Java. The greatest influence is the knowledge of accounting managers.
\end{abstract}

Keywords: organizational commitment; accounting manager knowledge; the implementation success of accounting information systems; SOE in West Java; multiple linier regression analysis

\begin{abstract}
Penelitian ini bertujuan untuk mengetahui besarnya pengaruh komitmen organisasional dan pengetahuan manajer akuntansi terhadap keberhasilan implementasi sistem informasi akuntansi secara simultan maupun parsial, dilakukan pada BUMN di Jawa Barat. Metode yang digunakan adalah metode deskriptif dan verifikatif. Jumlah sampel sebanyak 33 perusahaan, dengan teknik sampel acak sederhana. Jenis data adalah data primer yang diperoleh melalui kuesioner yang disebar kepada manajer bagian akuntansi. Analisis yang digunakan adalah analisis regresi linier berganda. Hasil penelitian menunjukkan bahwa tingkat komitmen organisasional dan keberhasilan implementasi sistem informasi akuntansi manajemen pada kategori tinggi, pengetahuan manajer akuntansi pada kategori sangat tinggi. Secara simultan maupun parsial komitmen organisasional dan pengetahuan manajer akuntansi berpengaruh positif dan signifikan terhadap keberhasilan implementasi sistem informasi akuntansi pada BUMN di Jawa Barat. Pengaruh terbesar adalah pengetahuan manajer akuntansi.
\end{abstract}

Kata Kunci: komitmen organisasional; pengetahuan manajer akuntansi; keberhasilan implementasi sistem informasi akuntansi; BUMN di Jawa Barat; analisis regresi linier berganda 


\section{PENDAHULUAN}

Teknologi informasi (TI) telah menjadi kebutuhan sekaligus persyaratan bagi organisasi dalam menjalankan bisnisnya. Secara prinsip, TI telah menjadi pemungkin (enabler) bagi organisasi dalam rangka mencapai tujuan (Abdillah \& Jogiyanto, 2011). Dengan semakin berkembangnya TI, maka dapat mengubah suatu organisasi dalam menjalankan usahanya, sehingga harus dilakukan perencanaan yang hati-hati untuk memastikan bahwa dengan adanya TI mampu meningkatkan pelayanan, efisiensi, dan profitabilitas (Louden \& Jane, 2012). Akuntansi adalah bahasa bisnis, yang digunakan setiap organisasi sebagai bahasa komunikasi saat berbisnis, yang pada dasarnya merupakan sistem informasi (Susanto, 2007). Menurut Mareen Link (2003) dalam Bagranoff, et al., (2010) dengan berkembangnya konsep akuntansi yang semula selalu dipicu oleh kertas, sekarang kondisi tersebut telah berubah karena akuntansi saat ini didorong oleh teknologi.

Akuntansi yang sudah berubah karena perkembangan teknologi, menjadi sistem informasi yang menyediakan laporan kepada para penggunanya mengenai aktivitas ekonomi dan kondisi perusahaan (Warren \& Parker, 2009). Pada tahun 2008, organisasi terus meningkatkan pengeluaran pada TI dan anggarannya terus meningkat, bahkan dalam menghadapi kemerosotan ekonomi yang potensial. Pengeluaran pada TI di Amerika tumbuh sebesar 2,3\%, Eropa 3,86\%, dan Asia-Pasifik 5,98\% (Kanarcus, 2008).

Berdasarkan hasil penelitian International Data Corporation (IDC, 2009) menyatakan bahwa perkiraan pertumbuhan belanja teknologi informasi di Indonesia berkisar $7.9 \%$ per tahun sampai tahun 2013. Pembelanjaan TI tersebut meliputi pengadaan perangkat keras, perangkat lunak, dan layanan TI. Peningkatan belanja TI dikarenakan manfaat TI dalam mendukung proses bisnis semakin nyata seiring dengan kompetisi bisnis yang semakin meningkat dan dinamis (Nugroho, 2011).

Sistem informasi yang baik adalah sistem yang mampu menghasilkan kinerja dan manfaat bagi penggunanya (Abdillah \& Jogiyanto, 2011). Bagi suatu perusahaan, sistem informasi akuntansi (SIA) dibangun dengan tujuan utama untuk mengolah data akuntansi yang berasal dari berbagai sumber menjadi informasi akuntansi yang diperlukan oleh berbagai macam pemakai untuk mengurangi risiko saat mengambil keputusan (Susanto, 2007).

Akuntansi sebagai sistem informasi dikembangkan dengan menggunakan TI untuk menghasilkan kinerja yang lebih baik dan nilai bagi organisasi, sehingga diperlukan pengukuran yang tepat untuk mengukur keberhasilan sistem informasi akuntansi (SIA) (Abdillah \& Jogiyanto, 2011). Salah satu bentuk perubahan dalam implementasi SIA adalah adanya solusi Enterprise
Resource Planning (ERP) yang memberikan aplikasi SIA untuk fungsi utama bisnis yang ada di organisasi (Susanto, 2007). ERP adalah model sistem informasi yang memungkinkan perusahaan mengotomatisasikan dan mengintegrasikan berbagai proses bisnis utamanya yang salah satunya SIA (Hall, 2011).

Pada kenyataannya masih terdapat masalah mengenai tingkat keberhasilan implementasi SIA yang tergabung dalam ERP. Survei yang dilakukan di Amerika pada tahun 2010 (Krigsman, 2010) menunjukkan bahwa 57\% implementasi sistem ERP memakan waktu lebih lama dari yang diharapkan dan 54\% melebihi anggaran yang telah ditetapkan. Selain itu, sebesar 32\% eksekutif dan $39 \%$ pekerja tidak puas dengan implementasi sistem ERP.

Menurut Choe (1996), keberhasilan penerapan sistem informasi akuntansi di perusahaan tidaklah mudah untuk dicapai dan sering kali menimbulkan masalah karena dipengaruhi oleh banyak faktor, antara lain: (1) keterlibatan pemakai; (2) dukungan pimpinan; (3) pelatihan dan pendidikan pemakai; (4) faktor kelompok kerja dalam organisasi; dan (5) faktor organisasi lainnya seperti ukuran organisasi, karakteristik tugas, dan lainlain. Menurut Burton, et al., (1992), di samping faktor organisasi seperti kompleksitas tugas, ukuran organisasi, faktor kepemimpinan, dan lain-lain, faktor individual seperti motivasi, kepuasan, dan kebermanfaatan bagi pemakai sangat menentukan keberhasilan penerapan sistem informasi akuntansi. Menurut Kaye (1990), keberhasilan penerapan sistem informasi akuntansi adalah masalah krusial di perusahaan, karena ditentukan oleh faktor situasi dan kondisi diterapkannya sistem informasi akuntansi tersebut, antara lain berkaitan erat dengan: (1) faktor lingkungan perusahaan; (2) isi (content) sistem informasi akuntansi yang digunakan, seperti tugas, struktur, teknologi, dan orang; dan (3) proses penerapan sistem informasi akuntansi.

Beberapa BUMN di Jawa Barat tengah melakukan implementasi dan ada yang telah selesai mengimplementasikan sistem informasi akuntansi yang tergabung dalam ERP. PT Telkom sebagai BUMN yang sudah mengaplikasikan ERP dengan menggunakan SAP sejak tahun 2002 telah menjadi perusahaan yang dipercaya berhasil dalam mengimplementasikan ERP (Syarifuddin, 2012). PT Kereta Api Indonesia (PT KAI) mengimplementasikan ERP dengan menggunakan SAP yang dimulai pada bulan Juni 2011 (Wahono, 2010). Implementasi ERP SAP bidang finansial (FICO) dan sumber daya manusia (HR) serta penerapan IT Governance yang mengacu pada COBIT (Control Objective For Information and Related Technology) dan ITIL (Information Technology Infrastructure Library) yang bertujuan mengontrol bisnis proses perusahaan (Public Relations PT KAI, 2012).

PT INTI melakukan transformasi terhadap integrasi seluruh proses bisnis melalui SAP Business All in One. Melalui SAP sistem informasi keuangan, pembukuan, 
perencanaan proyek, pembelian, administrasi penjualan, dan persediaan/pergudangan menjadi satu. Proyek implementasi SAP Business All in One dimulai pada bulan Maret 2011 - Januari 2012 (Syarifuddin, 2012). Penerapan solusi SAP ERP (Enterprise Resource Planning) di PT Pos Indonesia diimplementasikan sebagai sistem informasi keuangan terbaru bagi PT. Pos, yang diberi nama Sistem Informasi Keuangan (Simkug). Solusi SAP ERP memungkinkan PT Pos Indonesia membuat laporan keuangan akuntansi yang lebih cepat dan akurat, hal ini akan mendukung proses pengambilan keputusan dengan tepat dan cepat. Proses implementasi ini dilakukan dalam waktu 72 minggu dimulai dari tahun 2012 (Priguna, 2012).

PT Pindad sedang melakukan implemenasi ERP tahap tiga dengan menggunakan SPA yang terdiri dari enam modul yaitu Sales \& Distribution (SD) untuk fungsi pemasaran dan penjualan, Material Management (MM) untuk fungsi pengadaan \& gudang, Production Planning $(P P)$ untuk fungsi produksi, Quality Control (QC) untuk fungsi mutu dan pengujian, Plant Maintenance (PM) untuk fungsi pemeliharaan, dan Financial and Controlling (FICO) untuk fungsi keuangan dan biaya. Tahap pertama dan kedua telah selesai dilakukan pada tahun 2012 untuk Divisi Senjata, Divisi Munisi, dan Kantor Pusat. Untuk tahap ketiga ini dimulai pada bulan Juli 2013 pada empat divisi yang terletak di bawah Direktorat Produk Manufaktur yaitu Divisi Kendaraan Khusus, Divisi Tempa dan Cor, Divisi Mesin Industri dan Jasa, serta Divisi Bahan Peledak Komersial (Anggia, 2013).

Kompleksnya proses dan karakteristik sistem informasi akuntansi yang harus taat prosedur untuk menjalankan sistem informasi akuntansi, menuntut individu-individu pelaksana sistem informasi akuntansi memiliki daya bekerja yang kuat dalam diri mereka agar secara berkesinambungan dapat menjalankan proses sistem informasi akuntansi yang tercermin dalam komitmen organisasional (Adli, 2010). Menurut Chen, et al., (2002), komitmen organisasional adalah ikatan psikologi seorang karyawan terhadap perusahaan yang mendorong karyawan tersebut bekerja keras mencapai tujuan perusahaan. Mowday, et al., (1982) memberikan arti yang lebih orisinal tentang komitmen organisasional, bahwa komitmen organisasional memiliki tiga komponen utama: (1) Penerimaan atas nilai dan tujuan perusahaan; (2) Mendahulukan kepentingan perusahaan; dan (3) Keinginan untuk tetap menjadi karyawan dari sebuah perusahaan.

Menurut Doll (1995), komitmen organisasional dapat mempengaruhi keberhasilan penerapan sistem informasi akuntansi melalui tiga cara: (1) Dukungan manajemen yang dapat memastikan tersedianya pendanaan yang memadai untuk menjalankan sistem informasi akuntansi; (2) Melalui penetapan tujuan dan kebijakan perusahaan yang mendukung berjalannya sistem informasi akuntansi; dan (3) Pemberian skala prioritas untuk pengembangan sistem informasi akuntansi. Menurut Cerullo (1997), komitmen organisasional mempengaruhi keberhasilan penerapan sistem informasi akuntansi antara lain melalui: (1) Penetapan tujuan dan penilaian objektif perusahaan dalam penerapan sistem informasi akuntansi; (2) Evaluasi proposal proyek sistem informasi akuntansi yang objektif; (3) Pendefinisian informasi dan proses yang dibutuhkan; dan (4) Review program dan rencana untuk pengembangan sistem informasi akuntansi. Kemudian Lee dan Kim (1992) mengatakan bahwa komitmen organisasional mempengaruhi keberhasilan penerapan sistem informasi akuntansi melalui upaya formalisasi pengembangan sistem informasi akuntansi di perusahaan. Dengan formalisasi pengembangan sistem informasi akuntansi, kelemahan dalam pengalaman dan pembelajaran personal pengguna menjadi dapat diatasi.

Para manajer saat ini dituntut membekali dirinya dengan pengetahuan di bidang teknologi informasi khususnya yang digunakan dalam komputer serta menggunakannya di dalam sistem informasi akuntansi untuk membantu memproses data-data menjadi informasi akuntansi, sehingga dapat menghasilkan informasi yang berkualitas saat diperlukan (Susanto, 2007). Selain komitmen organisasional, keberhasilan penerapan sistem informasi akuntansi juga dipengaruhi oleh faktor utama lain yaitu pengetahuan manajer akuntansi/keuangan tentang sistem informasi akuntansi (Adli, 2010).

Sistem informasi akuntansi yang memadai bagi suatu organisasi, ditentukan oleh kemampuan dan kompetensi manajer dalam mengidentifikasi sistem informasi akuntansi yang dibutuhkan oleh organisasinya (Ambarriani, 2012). Kompleksnya sistem informasi akuntansi, luasnya lingkup transaksi akuntansi yang mencakup semua bagian perusahaan, dan adanya banyak prosedur dalam proses sistem informasi akuntansi mulai dari terjadinya transaksi sampai dihasilkannya laporan keuangan, menuntut seorang manajer keuangan memiliki kapasitas yang memadai untuk melakukan evaluasi atas trouble system dan kemudian mengambil tindakan yang cukup untuk mengatasi permasalahan tersebut, sehingga tidak berdampak terhadap siklus sistem informasi akuntansi secara keseluruhan (Adli, 2010).

Menurut Sabherwal, et al., (2006), kompleksnya proses sistem informasi akuntansi menuntut pengalaman seorang manajer keuangan dalam SIA (experience with AIS) dan pelatihan SIA (training in AIS), yang keduanya merupakan konstruk (user related construct) yang menentukan keberhasilan penerapan sistem informasi akuntansi. Menurut Choe (1996), pelatihan dan pendidikan pengembang, pengelola, dan pengguna sistem informasi akuntansi (training and education developer, owners, and user) merupakan faktor penentu keberhasilan penerapan sistem informasi akuntansi di perusahaan, karena dengan kompleksitas SIA dan 
beragamnya transaksi keuangan yang terjadi di seluruh bagian perusahaan memerlukan pengelolaan cermat dan berkelanjutan, agar dihasilkan laporan keuangan yang valid. Sedangkan Saunders dan Jones (1992), menggunakan istilah kompetensi manajer dan staf sistem informasi akuntansi (AIS manager and staff competence) sebagai faktor penentu keberhasilan penerapan sistem informasi akuntansi.

Berdasarkan uraian sebelumnya, identifikasi masalah dalam penelitian ini adalah seberapa besar pengaruh komitmen organisasional dan pengetahuan manajer akuntansi terhadap keberhasilan implementasi sistem informasi akuntansi, baik secara simultan maupun secara parsial.

Sistem yang baik adalah sistem yang mampu menghasilkan kinerja dan manfaat bagi penggunanya (Abdillah \& Jogiyanto, 2011). Begitu juga sistem informasi akuntansi yang diharapkan dapat bermanfaat bagi perusahaan dalam menjalankan kegiatan operasinya. Tujuan utama dari sistem informasi akuntansi bagi perusahaan yaitu mendukung fungsi penyediaan pihak manajemen, mendukung pengambilan keputusan pihak manajemen, dan mendukung operasional harian perusahaan (Hall, 2011). Selain itu sistem informasi akuntansi memiliki tujuan yang berkaitan untuk mengurangi risiko saat pengambilan keputusan bagi penggunanya (Susanto, 2007). Dengan tujuan akuntansi tersebut maka perlu dilakukan pengukuran terhadap keberhasilan implementasi sistem informasi akuntansi dalam mencapai tujuan yang diharapkan dari sistem tersebut.

Salah satu yang mendasari pengukuran terhadap keberhasilan implementasi sistem informasi pada umumnya adalah theory of reasoned action. Dari teori tersebut maka muncul model penerimaan teknologi (technology acceptance model) yang berkaitan dengan perilaku pengguna dalam menngakan sistem informasi yaitu kegunaan persepsian (perceived usefulness) dan kemudahan penggunaan persepsian (perceived ease of use) (Davis, 1989). Kemudian muncul model yang paling sering digunakan dalam mengukur keberhasilan sistem informasi adalah model DeLone dan McLean (DeLone dan McLean, 1992) yang kemudian diperbaharui pada tahun 2003. Model tersebut memberikan dimensi-dimensi yang digunakan dalam mengukur keberhasilan sistem informasi yang terdiri dari kualitas sistem, kualitas informasi, kualitas pelayanan, kepuasan pengguna, penggunaan, dampak individual, dan dampak organisasi.

Dalam konteks penelitian ini keberhasilan sistem informasi akuntansi didefinisikan keberhasilan implementasi sistem informasi akuntansi adalah intensitas penggunaan (use) sistem informasi akuntansi dalam pekerjaan sehari -hari dan kepuasan pengguna (user satisfaction) atas pemakaian sistem informasi akuntansi (Mollanazari \& Elahe, 2012; Ismail, 2009; Gledermen, 1998; Choe,1996). Berdasarkan definisi tersebut maka terdapat dua dimensi yang membentuk keberhasilan implementasi sistem informasi akuntansi yang pertama adalah penggunaan sistem informasi akuntansi berkaitan dengan frekuensi dan keinginan untuk menggunakan sistem informasi akuntansi (Choe, 1996). Dimensi yang kedua adalah kepuasan pengguna berkaitan dengan kecocokan antara kebutuhan pekerjaan dan fungsionalitas sistem yang merupakan respons dan umpan balik yang dimunculkan pengguna atas penggunaan sistem informasi akuntansi (Chin, et al., 1988; Iivari, 2005; Choe, 1996).

Komitmen organisasional adalah sebagai (1) suatu keinginan yang kuat untuk tetap menjadi anggota organisasi, (2) kesediaan untuk berusaha sebaik mungkin untuk kepentingan organisasi, dan (3) kepercayaan dan penerimaan yang kuat terhadap nilai-nilai dan tujuan organisasi (Luthans, 2005). Komitmen organisasional terdiri dari tiga dimensi yaitu komitmen afektif, komitmen berkelanjutan, dan komitmen normatif. Komitmen organisasional akan menunjukkan bagaimana seluruh karyawan di perusahaan akan mendukung implementasi sistem informasi akuntansi. Komitmen organisasional berkaitan dengan bagaimana seorang karyawan akan menerima sistem informasi akuntansi untuk mencapai tujuan perusahaan. Penelitian yang dilakukan oleh Basu, et al., (2002) menunjukkan bahwa semakin tinggi komitmen organisasional maka semakin tinggi keberhasilan sistem informasi, komitmen organisasional menunjukkan sikap dan keinginan karyawan dalam menggunakan sistem informasi akuntansi. Adapun penelitian lain menunjukkan adanya pengaruh positif dari komitmen organisasional terhadap kesuksesan implementasi sistem informasi (Essex, et al., 1998; Adli, 2010). Berdasarkan uraian tersebut maka dihipotesiskan, komitmen organisasional berpengaruh terhadap keberhasilan implementasi sistem informasi akuntansi.

Berikutnya pengetahuan manajer akuntansi didefinisikan sebagai keahlian dan keterampilan seorang manajer di bidang akuntansi yang diperoleh melalui pengalaman, pendidikan, dan pelatihan (Sabherwal, et al., 2006; Choe, 1996). Seorang manajer akuntansi memiliki keputusan terkait dengan penyediaan sistem informasi akuntansi yang sesuai dengan kegiatan operasi dan karakteristik perusahaan. Sehingga seorang manajer akan peduli terhadap kapabilitas dan teknologi yang tepat untuk sistem informasi akuntansi di perusahaan. Pada akhirnya pengetahuan manajer akuntansi diperlukan untuk memahami kebutuhan informasi perusahaan dan berdasarkan pengetahuan yang dimilikinya akan menerapkan sistem informasi akuntansi yang sesuai dengan kebutuhan informasi perusahaan (Ismail, 2009). Penelitian sebelumnya menunjukkan bahwa pengetahuan manajer akuntansi berpengaruh positif terhadap keberhasilan implementasi sistem informasi akuntansi (Kouser, et al., 2011; Ismail, 2009; Choe, 1996; Komala, 2012). Berdasarkan uraian tersebut maka dihipotesiskan pengetahuan manajer akuntansi berpengaruh terhadap keberhasilan implementasi sistem informasi akuntansi. 
Berdasarkan penelitian sebelumnya peneliti juga ingin melihat bagaimana pengaruh komitmen organisasional dan pengetahuan manajer akuntansi terhadap keberhasilan implementasi sistem informasi akuntansi. Penelitian yang sebelumnya hanya melihat secara parsial mengenai pengaruh masing-masing variabel tersebut terhadap keberhasilan implementasi sistem informasi akuntansi (Basu, et al., 2002; Essex, et al., 1998; Adli, 2010; Kouser, et al., 2011; Ismail, 2009; Choe, 1996; Komala, 2012). Sehingga dibuatlah hipotesis, komitmen organisasional dan pengetahuan manajer akuntansi secara bersama-sama berpengaruh terhadap keberhasilan implementasi sistem informasi akuntansi.

\section{METODE}

Definisi operasional variabel ditunjukkan pada Tabel 1 dan diukur pada skala ordinal. Populasi dalam penelitian ini adalah bagian akuntansi di BUMN yang berbadan hukum perseroan terbatas, berlokasi di Jawa Barat. Kelompok populasi berjumlah 50 perusahaan, dengan responden adalah manajer pada bagian akuntansi. Pengambilan sampel dilakukan dengan acak sederhana.

Hasil penyebaran dan pengumpulan sebanyak 50 kuesioner, respons kembali kuesioner sebanyak 33. Analisis data yang digunakan adalah analisis deskriptif dan analisis asosiatif. Sebelum melakukan analisis data maka dilakukan pengujian terhadap instrumen penelitian dengan menggunakan uji validitas dan reliabilitas. Analisis deskriptif digunakan untuk menjelaskan kondisi masing-masing variabel untuk setiap perusahaan dengan menggunakan tabel frekuensi. Analisis asosiatif menggunakan regresi linier berganda. Sebelumnya peneliti melakukan transformasi data dari skala ordinal ke interval menggunakan method of successive interval, juga uji normalitas, multikolonieritas, dan heteroskedastisitas. Model empiris adalah sebagai berikut:

$$
\operatorname{KISIA}=a+b_{1}(K O)+b_{2}(P M A)+e
$$

Keterangan:

KISIA $=$ Keberhasilan Implementasi Sistem Informasi Akuntansi

$\mathrm{KO}=$ Komitmen Organisasional

PMA = Pengetahuan Manajer Akuntansi

a $\quad=$ Konstanta

$\mathrm{b}_{1}-\mathrm{b}_{2}=$ Koefisien regresi variabel independen

e $\quad=$ Standar error/variabel di luar penelitian

\section{HASIL}

Berdasarkan pengujian validitas dan reliabilitas untuk kuesioner diperoleh bahwa butir setiap pertanyaan untuk seluruh variabel valid dan reliabel. Hasil analisis deskriptif menunjukkan tingkat komitmen organisasional terletak pada kategori tinggi atau $65,22 \%$, tingkat pengetahuan manajer akuntansi terletak pada kategori sangat tinggi atau $83,37 \%$, tingkat keberhasilan implementasi SIA terletak pada kategori tinggi atau $75,29 \%$. Hasil uji asumsi klasik menunjukkan data berdistribusi normal, tidak terjadi multikolinieritas, dan tidak terjadi heteroskedastisitas pada model regresi.

Hasil perhitungan untuk mengetahui model empiris dapat dilihat pada Tabel 2. Besarnya konstanta (a) sebesar -5,896, $b_{1}$ sebesar 0,494, dan $b_{2}$ sebesar 1,219. Besarnya pengaruh secara keseluruhan sebesar $44,1 \%$ terdiri dari 10,6\% pengaruh komitmen organisasional dan 33,4\% pengaruh pengetahuan manajer akuntansi (Tabel 3 dan Tabel 4). Pengujian hipotesis menunjukkan bahwa seluruh hipotesis penelitian diterima (Tabel 5).

\section{PEMBAHASAN}

Hasil deskripsi mengenai variabel komitmen organisasional menunjukkan hasil yang baik sehingga masuk dalam kategori tinggi. Kondisi ini dicermikan melalui ketiga dimensi yang terdiri dari affective commitment, continuance commitment, dan normative commitment yang masing-masing berada dalam kategori tinggi, cukup, dan tinggi.

Berdasarkan pencapaian skor tersebut dapat dinyatakan bahwa BUMN di Jawa Barat telah memiliki tingkat affective commitment yang baik, yang tercermin dari rasa memiliki, rasa keterikatan emosional, dan makna personal terhadap organisasi dari manajer akuntansi yang sudah tinggi pada BUMN di Jawa Barat. Demikian juga dengan tingkat continuance commitment juga sudah cukup baik, yang tercermin dari tingkat pertimbangan untuk tetap berkerja, kesadaran untuk tetap berada dalam organisasi, dan kerugian meninggalkan organisasi pada BUMN di Jawa Barat. Kemudian tingkat normative commitment juga sudah baik, yang tercermin dari keterikatan dengan organisasi dan kesetiaan terhadap organisasi yang juga sudah tinggi pada BUMN di Jawa Barat.

Penelitian deskriptif variabel komitmen organisasional ini sesuai dengan teori, bahwa ada banyak faktor yang mempengaruhi tingkat komitmen organisasional karyawan di sebuah perusahaan. Menurut Mowday, et al., (1982), ada empat faktor yang mempengaruhi tingkat komitmen organisasional seorang karyawan, yaitu: (1) faktor karakteristik individu, antara lain: pendidikan, dorongan untuk berprestasi, masa kerja, dan usia; (2) faktor karakteristik pekerjaan, antara lain: tantangan pekerjaan, umpan balik, tekanan pekerjaan, identifikasi tugas, kejelasan peran, pengembangan diri, karier, dan tanggung jawab; (3) faktor karakteristik organisasi, antara lain: desentralisasi dan tingkat partisipasi dalam pengambilan keputusan; dan (4) faktor sifat dan kualitas pekerjaan. Kemudian menurut Dessler (2003), ada tujuh faktor yang mempengaruhi komitmen organisasi, yaitu: (1) 
nilai kemanusiaan; (2) komunikasi dua arah yang komprehensif; (3) rasa kebersamaan dan kerukunan; visi dan misi organisasi; (5) nilai sebagai dasar rekrutmen; (6) kestabilan kerja; dan (7) penghargaan.

Hasil deskripsi mengenai variabel pengetahuan manajer akuntansi menunjukkan hasil yang baik sehingga masuk dalam kategori tinggi. Kondisi ini dicermikan melalui ketiga dimensi yang terdiri dari experience in accounting, training in accounting, dan education in accounting yang masing-masing berada dalam kategori sangat tinggi, tinggi, dan sangat tinggi.

Berdasarkan pencapaian skor tersebut dapat dinyatakan bahwa manajer akuntansi pada BUMN di Jawa Barat telah memiliki tingkat pengalaman bekerja di bidang akuntansi yang telah memadai, yang tercermin dari lamanya bekerja di bidang akuntansi, pengalaman di bidang akuntansi, dan adanya pandangan akan pentingnya pengalaman dalam bidang akuntansi bagi seorang manajer akuntansi. Demikian juga dengan pelatihan di bidang akuntansi, terlihat bahwa manajer akuntansi pada BUMN di Jawa Barat juga telah menjalani pelatihan yang memadai di bidang akuntansi, yang tercermin dari keikutsertaan pelatihan yang memadai, adanya persyaratan mengenai pelatihan yang harus diikuti untuk menjadi seorang manajer, dan pandangan akan pentingnya pelatihan bagi seorang manajer akuntansi. Kemudian juga untuk pendidikan di bidang akuntansi, terlihat bahwa manajer akuntansi pada BUMN di Jawa Barat telah memiliki pendidikan yang memadai di bidang akuntansi, yang tercermin dari latar belakang pendidikan yang dimiliki, persyaratan pendidikan di bidang akuntansi untuk menjadi manajer akuntansi, dan pandangan mengenai pentingnya pendidikan di bidang akuntansi.

Hasil deskripsi mengenai variabel keberhasilan implementasi SIA menunjukkan hasil yang baik sehingga masuk dalam kategori tinggi. Kondisi ini dicermikan melalui kedua dimensi yang terdiri dari kepuasan pengguna dan intensitas penggunaan yang keduanya berada dalam kategori tinggi.

Berdasarkan kategori pencapaian skor tersebut dapat dinyatakan bahwa BUMN di Jawa Barat telah memiliki tingkat kepuasan pengguna atas sistem informasi akuntansi yang baik, yang tercermin dari memberikan informasi yang relevan, memberikan informasi yang akurat, informasi yang dibutuhkan tepat waktu, kapabilitas sistem, dan pembelajaran dalam penggunaan sistem. Demikian juga dengan tingkat intensitas penggunaan sistem informasi akuntansi juga sudah baik, yang tercermin pada frekuensi penggunaan sistem informasi akuntansi dan acuan dalam tugas sehari-hari yang tinggi pada BUMN di Jawa Barat.

Tingkat keberhasilan penerapan sistem informasi akuntansi pada BUMN di Jawa Barat belumlah mencapai tahap yang ideal, karena kondisi yang ideal semestinya masuk dalam kategori sangat tinggi. Belum idealnya tingkat keberhasilan implementasi sistem informasi akuntansi pada BUMN di Jawa Barat adalah relevan dengan fenomena yang diangkat dalam penelitian ini, bahwa masih adanya temuan BPK terhadap beberapa BUMN.

Penelitian deskriptif variabel keberhasilan penerapan sistem informasi akuntansi ini sesuai dengan teori, bahwa ada beberapa faktor yang mempengaruhi keberhasilan penerapan sistem informasi akuntansi. Menurut Choe (1996), keberhasilan penerapan sistem informasi akuntansi di perusahaan tidaklah mudah untuk dicapai dan sering kali menimbulkan masalah karena dipengaruhi oleh banyak faktor, antara lain: (1) keterlibatan pemakai; (2) dukungan pimpinan; (3) Pelatihan dan pendidikan pemakai; (4)faktor kelompok kerja dalam organisasi; dan (5) faktor organisasi lainnya seperti ukuran organisasi, karakteristik tugas, dan lainlain. Menurut Burton, et al., (1992), di samping faktor organisasi seperti kompleksitas tugas, ukuran organisasi, faktor kepemimpinan, dan lain-lain, faktor individual seperti motivasi, kepuasan, dan kebermanfaatan bagi pemakai sangat menentukan keberhasilan penerapan sistem informasi akuntansi. Menurut Kaye (1990), keberhasilan penerapan sistem informasi akuntansi adalah masalah krusial di perusahaan, karena ditentukan oleh faktor situasi dan kondisi mengenai sistem informasi akuntansi tersebut diterapkan, antara lain berkaitan erat dengan: (1) faktor lingkungan perusahaan; (2) isi (content) sistem informasi akuntansi yang digunakan, seperti tugas, struktur, teknologi, dan orang; dan (3) proses penerapan sistem informasi akuntansi.

Hasil pengujian pengaruh simultan menunjukkan bahwa nilai Fhitung $=11,824>$ Ftabel $=3,315$, berarti menolak hipotesis nol. Berdasarkan hasil pengujian tersebut, dapat disimpulkan bahwa secara statistik variabel komitmen organisasional dan pengetahuan manajer akuntansi secara bersama-sama berpengaruh positif dan signifikan terhadap keberhasilan implementasi sistem informasi akuntansi.

Hasil ini dapat diinterpretasikan bahwa, keberhasilan implementasi sistem informasi akuntansi pada BUMN di Jawa Barat dapat dicapai bila karyawan dan manajer pada BUMN di Jawa Barat memiliki tingkat komitmen organisasional yang tinggi. Temuan ini sejalan dengan teori, bahwa dari sekian banyak faktor yang mempengaruhi keberhasilan implementasi sistem informasi akuntansi, komitmen organisasional adalah faktor utama dan sangat penting, karena inti dari komitmen organisasional adalah keterikatan dan loyalitas seorang karyawan kepada perusahaan yang akan mendorong mereka untuk selalu bekerja dalam berbagai situasi di perusahaan (Larsen, 2003). Kemudian Saunders and Jones (1992), mengatakan bahwa komitmen organisasional sebagai faktor organisasi yang sangat penting untuk keberhasilan penerapan sistem informasi akuntansi disamping faktor lain seperti: integrasi SIA dengan perencanaan perusahaan, kualitas output SIA, efisiensi operasi 
SIA, sikap pemakai/manajemen, kompetensi staf pelaksana SIA, dan lain-lain. Kemudian Choe (1996) juga menjadikan komitmen organisasional sebagai faktor penentu utama keberhasilan penerapan sistem informasi akuntansi disamping faktor-faktor lainnya, seperti kapabilitas personal SIA dalam bidang teknik, keterlibatan pemakai, training dan pendidikan pemakai, komite pengarah, lokasi departemen SIA, formalisasi pengembangan SIA, dan ukuran organisasi.

Demikian juga dengan pengetahuan manajer akuntansi, tingkat pengetahuan manajer juga memiliki peran penting dalam keberhasilan penerapan sistem informasi akuntansi, temuan penelitian ini juga sesuai dengan pendapat Choe (1996), bahwa pelatihan dan pendidikan pengembang dan pemakai merupakan aspek penting pembentuk pengetahuan, bersamaan dengan faktor-faktor lain merupakan penentu keberhasilan penerapan sistem informasi akuntansi. Kemudian Saunders and Jones (1992), mengatakan bahwa kompetensi staf sistem informasi akuntansi adalah faktor penentu keberhasilan penerapan sistem informasi akuntansi.

Selanjutnya, dilihat dari total pengaruh secara bersama-sama variabel komitmen organisasional dan pengetahuan manajer akuntansi terhadap keberhasilan implementasi sistem informasi akuntansi, menunjukkan hasil sebesar 44,1\% sedangkan sisanya sebesar 55,9\% dipengaruhi faktor lain seperti kondisi fasilitas pemakai akhir, formalisasi pengembangan SIA, peran komite pengarah, lokasi departemen SIA, dan ukuran organisasi (Rayner dan Watson, 1995; Choe, 1996; Essex, et al., 1998, dan Suratman dan Ridwan, 2017). Kemudian faktor kompleksitas tugas, ukuran organisasi, dan faktor kepemimpinan (Burton, et al., 1992).

\section{KESIMPULAN}

Komitmen organisasional dan pengetahuan manajer akuntansi berpengaruh positif dan signifikan terhadap keberhasilan implementasi SIA baik secara simultan maupun parsial. Secara parsial, pengaruh variabel pengetahuan manajer akuntansi memiliki pengaruh yang lebih besar terhadap variabel keberhasilan implementasi SIA dibandingkan dengan variabel komitmen organisasional. Besarnya pengaruh pengetahuan manajer akuntansi sebesar 33,4\% dan komitmen organisasional sebesar $10,7 \%$ sehingga pengaruh secara bersamasama adalah sebesar 44,1\%. Faktor-faktor lain yang mempengaruhi keberhasilan implementasi SIA seperti kualitas aplikasi yang dikembangkan, keterlibatan pengguna dalam pengembangan, integrasi dengan perencanaan perusahaan, kondisi yang memfasilitasi penggunaan, kualitas staf, formalisasi pengembangan, peran komite pengarah, lokasi departemen SIA, dan ukuran organisasi.

\section{DAFTAR PUSTAKA}

Abdillah, W. \& Jogiyanto H.M. 2011. Sistem Tata Kelola Teknologi Informasi. Yogyakarta: Penerbit Andi.

Adli. 2010. Pengaruh Komitmen Organisasional dan Pengetahuan Manajer Terhadap Keberhasilan Penerapan Sistem Informasi Akuntansi dan Dampaknya Terhadap Kinerja Keuangan Perusahaan (Survei Pada BUMN di Indonesia).

Ambarriani, A. S. 2012. Pengaruh Pengetahuan Manajer Terhadap Gaya Penggunaan Informasi Akuntansi Manajemen dan Activity Based Management serta Implikasinya pada Penerapan Diagnosis Related Group. Working Paper. Pusat KP-MAK UGM.

Anggia. 2013. Kick Off Implementasi Erp Tahap 3 di PT Pindad (Persero). Ruang Publik PT Pindad. Melalui http://www.pindad.com/kick-off-implementasi-erptahap-3-di-pt-pindad-persero [03/06/13].

Basu, V., Edward, H., Albert, L. L., Vijay, S. 2002. The Impact of Organizational Commitment, Senior Management Involvement, and Team Involvement on Strategic Information Planning. Information \& Management, Vol. 39, No. 6, pages 513-524.

Bagranoff, N.A., Simkin, M.G. and Norman, C.S., 2010. Core Concept Accounting Information Systems. George Hoffman.

Burton, F.G., Chen, Y.N., Grover, V. and Stewart, K.A., 1992. An application of expectancy theory for assessing user motivation to utilize an expert system. Journal of Management Information Systems, 9(3), pp.183-198.

Cerullo, M.J. 1997. Information Systems Success Factors. Journal of Systems Management, Vol. 31, No. 12, pages 10-19.

Chen, Z.X., Tsui, A.S., and Farh, J.L. 2002. Loyality to Supervisors vs. Organizational Commitment: Relationships to Employee performance in China. Journal of Occupational and Organizational Psychology, Vol. 75, No. 3, page 339-356.

Chin, J.P., Diehl, V.A. and Norman, K.L. 1988. Development of an Instrument Measuring User Satisfaction of the Human-Computer Interface. CHI'88 Conference Proceedings: Human Factors in Computing Systems, NY: Association for Computing Machinery, pp. 213-218.

Choe, J. M. 1996, The Relationships among Performance of Accounting Information Systems, Influence Factors, and Evolution Level of Information Systems, Journal Management Information Systems, Vol. 12, No. 4, page 215-239.

Davis, F. D.1989. Perceived Usefulness, Perceived Ease of Use, and User Acceptance of Information Technology. MIS Quarterly, Vol. 13, No. 3, pages 319-340.

DeLone, W. H., \& E. R. McLean. 1992. Information System Success: The Quest for The Dependent Variable. Information Systems Research, Vol.3, No. 1, pages 60-95. 
Dessler, G. 2003. Human Resource Management. New Jersey: Prentice Hall, Upper Saddle River, NJ.

Doll, W.J. 1995. Avenues for Top Management Involvement in Successful MIS Development. MIS Quarterly, Vol. 9, No. 1, pages 17-35.

Essex, P.A., Magal, S.R. and Mateller, D.E. 1998. Determinants of Information Center Success. Journal of Management Information System, Vol. 15, No. 2, pages 95-117.

Glederman, M. 1998. The Relation between User Satisfaction, Usage of Information Systems and Performance. Information \& Management, Vol. 34, No. 1, pages 11-18.

Hall, J. A. 2011. Accounting Information Systems 7 ed. USA: South-Western Cengange Learning.

Iivari, J. 2005. An Empirical Test of The DeLone and McLean Model of Information Success. The DATA $B A S E$ for Advances in Information Systems, Vol. 36, No. 2, pages 8-27.

Ismail, N. A. 2009, Factors Influencing AIS Effectiveness Among Manufacturing SMEs: Evidence From Malaysia, EJISDC, Vol. 38, No. 10, page 1-19.

Kanarcus, C. 2008. Gartner: Global IT spending growth stable. Infoworld News. Melalui http:// www.infoworld.com/t/business/gartner-global-itspending-growth-stable-523 [03/06/13].

Kaye, G.R. 1990. Information System Successes and Failures: Research Finding from the Compunding Industry. Jurnal of Information Technology, Vol. 5, page: 73-83.

Komala, A. R. 2012. The Influence of The Accounting Manager Knowledge and The Top Management Support to The Accounting Information System and It's Impact on The Quality of Accounting Information: Survey in Management Institution of Zakat in Bandung. 3rd International Conference on Business and Economic Research - 3rd ICBER 2012, pp. 1183-1199.

Kouser, R., Rana, G. and Shahzad, F.A., 2011. Determinants of AIS effectiveness: Assessment thereof in Pakistan. International Journal of Contemporary Business Studies, 2(12), pp.6-21.

Krigsman, M. 2010. ERP failure: New research and statistics. ZDNet's News. Melalui http://www.zdnet. com/blog/projectfailures/erp-failure-new-researchand-statistics/8253 [03/06/14].

Larsen, K.R., 2003. A taxonomy of antecedents of information systems success: variable analysis studies. Journal of Management Information Systems, 20(2), pp.169-246.

Lee, J.J., and Kim, S.H. 1992. The Relationship Between Procedural Formalization in MIS Development and MIS Success. Information and Management, Vol. 22, No. 2, pages 89-111.
Louden, K. C. \& Jane, P. L. 2012. Management Information Systems: Managing the Digital Firm 12 ed. New Jersey: Pearson Education, Inc.

Luthans, F. 2005. Organizational Behavior. Tenth Edition. New York: McGraw-Hill.

Mollanazari, M. \& Elahe, A. 2012. The Effects of Task, Organization and Accounting Information Systems Characteristics on The Accounting Information Systems Performance in Tehran Stock Exchange. International Journal of Innovation, Management, and Technology, Vol. 3, No. 4, pages 443-448.

Mowday, R.T., Porter, L.W., and Steers, R.M. 1982. Employee Organization Linkages. Academic Press.

Nugroho, E. S. 2011. Dampak Penerapan Prioritas Investasi Bidang Teknologi Informasi Mennggunakan Quality Function Deployment (QFD) Terhadap Tingkat Keselarasan antara Strategi Bisnis dan Strategi TI. Seminar Nasional Aplikasi Teknologi Informasi, page F 66-73.

Priguna, S. 2012. SAP ERP Tingkatkan Efisiensi Bisnis PT Pos Indonesia. Chip News. Melalui http://chip. co.id/news/general/3308/sap_erp_tingkatkan_ efisiensi_bisnis_pt_pos_indonesia [03/06/13].

PT KAI. 2012. Laporan Tahunan PT Kereta Api Indonesia Tahun 2011. Bandung: Public Relations PT KAI.

Rayner, R.K., and Watson, H.J. 1995. The Keys to Executive Information System Success. Journal of Management Information System. 12(2): 83-98.

Sabherwal, R., Jeyaraj, A., and Chowa, C. 2006. Information System Success: Individual and Organizational Determinants. Management Science, Vol. 52, No. 12, pages 1849-1864.

Saunders, C.S., and Jones, J.W. 1992. Measuring Performance of the Information Systems Function. Journal of Management Information System, Vol. 8, No. 4, pages 63-82.

Suratman, S. S., \& Ridwan, M. 2017. Implementation of accounting information systems in state-owned enterprises in West Java, Indonesia. International Journal of Economic Research, 14(3), 29-41.

Susanto, A. 2007. Sistem Informasi Akuntansi: Struktur Pengendalian Resiko Pengembangan. Bandung: Lingga Jaya.

Syarifuddin, D. 2012. SAP Menjadi Business Enabler bagi Transformasi Perusahaan yang Berkelanjutan di PT Industri Telekomunikasi Indonesia (Persero). Jagat Review.

Wahono, T. 2010. PT KAI Implementasi SAP ERP. Kompas Tekno. Melalui http://tekno.kompas.com/ $\mathrm{read} / 2010 / 06 / 10 / 0949169 / \mathrm{PT} . K A I . I m p l e m e n t a s i$

Warren, S. and Parker, L., 2009. Bean counters or bright young things?. Qualitative Research in Accounting \& Management. 
Tabel 1. Operasionalisasi Variabel

\begin{tabular}{|c|c|c|}
\hline Variabel & Dimensi & Indikator \\
\hline \multirow{3}{*}{$\begin{array}{l}\text { K o m i } \mathrm{t} m \text { e } \mathrm{n} \\
\text { Organisasional } \\
\left(\mathrm{X}_{1}\right) \\
\text { Referensi: } \\
\text { Luthans (2005) }\end{array}$} & $\begin{array}{l}\text { Affective } \\
\text { Commitment }\end{array}$ & $\begin{array}{l}\text { 1. Rasa memiliki } \\
\text { 2. Rasa keterkaitan emosional } \\
\text { 3. Makna personal terhadap } \\
\text { organisasi }\end{array}$ \\
\hline & $\begin{array}{l}\text { Continuance } \\
\text { Commitment }\end{array}$ & $\begin{array}{l}\text { 1. Pertimbangan untuk tetap } \\
\text { bekerja } \\
\text { 2. Kesadaran untuk tetap } \\
\text { berada dalam organisasi } \\
\text { 3. Kerugian meninggalkan } \\
\text { organisasi }\end{array}$ \\
\hline & $\begin{array}{l}\text { Normative } \\
\text { Commitment }\end{array}$ & $\begin{array}{l}\text { 1. Keterikatan dengan organisasi } \\
\text { 2. Kesetiaan terhadap organisasi }\end{array}$ \\
\hline \multirow[t]{3}{*}{$\begin{array}{l}\text { P e } n g \text { e } t \text { a } h \text { u a n } \\
\text { Manajer Akuntansi } \\
\left(\mathrm{X}_{2}\right) \\
\text { Referensi: } \\
\text { Sabherwal, et } \\
\text { al., (2006); Choe } \\
(1996)\end{array}$} & $\begin{array}{l}\text { Experience } \\
\text { in } \\
\text { Accounting }\end{array}$ & $\begin{array}{l}\text { 1. Lama bekerja di bidang } \\
\text { akuntansi } \\
\text { 2. Pengalaman di bidang } \\
\text { akuntansi } \\
\text { 3. Pentingnya pengalaman di } \\
\text { bidang akuntansi }\end{array}$ \\
\hline & $\begin{array}{l}\text { Training in } \\
\text { Accounting }\end{array}$ & $\begin{array}{l}\text { 1. Banyaknya pelatihan } \\
\text { akuntansi yang diikuti } \\
\text { 2. Syarat pelatihan di bidang } \\
\text { akuntansi } \\
\text { 3. Pentingnya pelatihan bidang } \\
\text { akuntansi }\end{array}$ \\
\hline & $\begin{array}{l}\text { Education in } \\
\text { Accounting }\end{array}$ & $\begin{array}{l}\text { 1. Latar belakang pendidikan } \\
\text { di bidang akuntansi } \\
\text { 2. Syarat pendidikan di bidang } \\
\text { akuntansi } \\
\text { 3. Pentingnya pendidikan di } \\
\text { bidang akuntansi }\end{array}$ \\
\hline Keberhasilan & Kepuasan & 1. Memberikan informasi yang \\
\hline Implementasi & Pengguna & \\
\hline $\begin{array}{l}\text { Sistem Informasi } \\
\text { Akuntansi (Y) }\end{array}$ & & $\begin{array}{l}\text { 2. Memberikan informasi yang } \\
\text { akurat. }\end{array}$ \\
\hline $\begin{array}{l}\text { Referensi: } \\
\text { Suratman \& Ridwan }\end{array}$ & & 3. Informasi yang dibutuhkan \\
\hline $\begin{array}{l}\text { Suratman \& Ridwan } \\
\text { (2017); Mollanazari, } \\
\text { et al., (2012); Ismail } \\
\text { (2009); Iivari (2005) }\end{array}$ & & $\begin{array}{l}\text { tepat waktu. } \\
\text { 4. Kapabilitas sistem. } \\
\text { 5. Pembelajaran dalam } \\
\text { penggunaan sistem. }\end{array}$ \\
\hline Gledermen,(1998); & Intensitas & 1. Frekuensi penggunaan \\
\hline $\begin{array}{l}\text { Choe (1996); Chin, } \\
\text { et al., (1988) }\end{array}$ & Penggunaan & $\begin{array}{l}\text { 2. Acuan dalam tugas sehari- } \\
\text { hari }\end{array}$ \\
\hline
\end{tabular}

Tabel 2. Hasil Perhitungan Regresi Linier Berganda

\begin{tabular}{lcc}
\hline & \multicolumn{2}{c}{ Unstandardized Coefficients } \\
\cline { 2 - 3 } Keterangan & $\mathrm{B}$ & Std. Error \\
\hline (Constant) & -5.896 & 12.137 \\
KO $\left(\mathrm{X}_{1}\right)$ & .494 & .190 \\
PMA $\left(\mathrm{X}_{2}\right)$ & 1.219 & .280 \\
\hline
\end{tabular}

Dependent Variable: Keberhasilan Implementasi SIA (Y)

Tabel 3. Tabel R Square Koefisien Determinasi

\begin{tabular}{ccccc}
\hline Model & $\mathrm{R}$ & R Square & $\begin{array}{c}\text { Adjusted } \\
\text { R Square }\end{array}$ & $\begin{array}{c}\text { Std. Error of the } \\
\text { Estimate }\end{array}$ \\
\hline 1 & $.664^{\mathrm{a}}$ & .441 & .404 & 7.25765 \\
\hline
\end{tabular}

a. Predictors: (Constant), $\mathrm{X}_{2}, \mathrm{X}_{1}$

Tabel 4. Tabel Perhitungan Koefisien Determinasi Parsial

\begin{tabular}{lccc}
\hline Variabel & $\begin{array}{l}\text { Zero Order } \\
\text { Correlations }\end{array}$ & $\begin{array}{c}\text { Standardized } \\
\text { Coefficients (Beta) }\end{array}$ & $\begin{array}{l}\text { B e s a r a n } \\
\text { Pengaruh }(\mathrm{Kd})\end{array}$ \\
\cline { 2 - 4 } & $\mathrm{A}$ & $\mathrm{B}$ & $\mathrm{C}=\mathrm{A} \times \mathrm{B}$ \\
\hline $\mathrm{X}_{1}$ & 0.298 & 0.357 & 0.106386 \\
$\mathrm{X}_{2}$ & 0.561 & 0.596 & 0.334356 \\
\hline \multicolumn{2}{l}{ Total Pengaruh } & & 0.440742 \\
\hline
\end{tabular}

Tabel 5. Pengujian Hipotesis

\begin{tabular}{ccccc}
\hline Keterangan & $\mathrm{H} 1$ & $\mathrm{H} 2$ & $\mathrm{H} 3$ & Kesimpulan \\
\hline t-hitung/t-kritis & $2.600 /$ & & & $\mathrm{H}_{1}$ diterima \\
& 2.042 & & & \\
t-hitung/t-kritis & & $4.346 /$ & & $\mathrm{H}_{1}$ diterima \\
& & 2.042 & & \\
f-hitung/f-kritis & & & $11.824 /$ & $\mathrm{H}_{1}$ diterima \\
& & & 3.315 & \\
\hline
\end{tabular}

Sumber:Hasil pengolahan data 